\title{
Economics of Mushroom (Agaricus bisporus) Production in a Selected Upazila of Bangladesh
}

\author{
Basanta K. Barmon*, Imrana Sharmin, Parvez K. Abbasi and Al Mamun \\ Department of Economics, East West University, Dhaka, Bangladesh \\ *Corresponding author and Email: bkbarmon@yahoo.com
}

Received: 15 May $2012 \quad$ Accepted: 15 November 2012

\begin{abstract}
A study was conducted during 2011 to estimate profit, benefit cost ratio (BCR) and household income of mushroom production and also to explore the problems of producing mushroom and its marketing channels in Bangladesh. Thirty samples were randomly selected and information on mushroom production was collected using comprehensive questionnaire from Savar Upazila in Dhaka district. Mushroom was found to be a profitable agricultural enterprise (22,888 taka per farm). The benefit cost ratio (BCR) was 1.55 . The average family household income was about Tk. 43,731. Usually, three intermediaries (mushroom office, wholesalers and retailers) are involved in the marketing channels of mushroom. The marketing margin of mushroom for farm-gate to wholesalers and wholesalers to retailers were taka 50 and 70 per $\mathrm{kg}$, respectively. It was revealed that rich and middle income group people were the main mushroom customers. Even though mushroom is a profitable enterprise, the producers faced numerous problems regarding mushroom production and marketing.
\end{abstract}

\section{Keywords: Mushroom production, profit, benefit cost ratio (BCR), marketing channel, problems, Bangladesh}

\section{Introduction}

Mushroom (Agaricus bisporus) production is a lucrative and profitable cottage industry for lowincome rural households (Lelley, 1988) and this industry is providing full or part time employment to rural and urban poor and marginal people in many developing countries (Ferchak and Croucher, 2001). Now mushroom is being cultivated in more than 100 countries of the world and the estimated total production is over 12 million tons (Suman and Sharma, 2007). Mushroom is considered as one of the important food items since ancient time and its consumption is being increased over the period for its significant role in human health, nutrition and diseases (Suzuki and Oshima, 1976; Uddin, et al., 2011). The edible mushrooms are also good source of protein, vitamins and minerals (Khan et al., 1981).

Recently, unemployment is increasing rapidly both in developed and developing countries. In this situation, self-employment can be one important way to increase employment rate for small, marginal poor farm households for generating employment and earning extra money. They can easily cultivate mushroom in their home yard because it requires small piece of land where mushrooms can be grown.

However, market linkage is the most appropriate in the context of the farmers' involvement and the market to supply goods to consumers (KIT et al., 2006; and Shepherd, 2007). Usually, marketing channel links the producers and 
consumers, and thereby supplying goods from producers to consumers. A large number of intermediaries are involved in the marketing channels and they earn their daily livelihoods.

A few studies have been conducted which have focused on the production system of mushroom in Bangladesh (Kamal et al., 2009; Zamil and Cadilhon, 2009; Amin, 2002; Amin and Ruhul 2008; Sarker et al., 2007; and Uddin et al., 2011). In addition, a large number of researchers have been conducting research on mushroom related production system and management (Bano et al., 1979; Block et al., 1958; Han et al., 1977; Jong and Peng, 1975; Khan et al., 1981) in India, Nepal, China, Philippines, Thailand, Taiwan, Hong Kong and Pakistan. Work is also being done on human health, nutrition and diseases in other countries in the world (Agrahar-Murugkar and Subbulakshmi, 2005; Cheung and Cheung, 2005; Gunde-Cimerman, 1999; Hawksworth, 2001). However, the profit, benefit cost ratio (BCR), marketing channels and problems and constraints of mushroom production in Bangladesh has not been analyzed explicitly. The present study was therefore, undertaken to estimate and explore profit, benefit-cost ratio (BCR), marketing channels and problems and constraints of mushroom production in Bangladesh, and to provide suggestions and recommendations to generate policy implications for the further development of mushroom production in Bangladesh.

\section{Methodology}

The study was conducted during 2011. Based on the objectives of the study, primary data were used in the present study. Savar upazila in Dhaka district was purposively selected because a large number of households are engaged in mushroom production in this upazila for their daily livelihood. Thirty (30) sample households were randomly selected and information was collected on inputs and outputs, problems and constraints of mushroom production and the socio-economic characteristics of mushroom producers through a comprehensive pre-scheduled questionnaire.
Data were analysed following both tabular and statistical methods.

\subsection{Estimation of gross revenue, net profit and agricultural income}

Gross revenue was calculated by multiplying the total volume of production of enterprises by the farm gate price. Net profit was calculated by subtracting total production cost (fixed and variable cost) from gross revenue. Total agricultural income from mushroom farming included net profit from mushroom farming (3 months), opportunity cost of family labor, opportunity cost of rent, and agricultural income without mushroom cultivation ( 3 months).

\section{Results and Discussion}

\subsection{Socio-economic characteristics of mushroom producers}

The socio-economic characteristics of the sampled mushroom producers are presented in Tables 1, 2 and 3.

\subsubsection{Age of the producers}

Age is an important demographic factor to make a decision regarding the operation of any type of business. In case of mushroom cultivation the sampled producers were very young (Table 1). About 50 per cent of the sampled producers' age varied between 20 and 30 years, followed by 30 per cent producers' age ranging from 30 to 40 years. Only 20 per cent of the total producers' age was between 40 to above 50 years. Thus, it appeared that young generations are showing interest to produce mushroom in Bangladesh.

\subsubsection{Education of the producers}

Education makes a person more confident, strong and creates ability to think and decide quickly. The literacy level of the respondents is shown in Table 2.

Literacy levels of the sampled mushroom producers vary from illiterate to graduate level. Thirty three (33\%) per cent of the producers had primary education, 20 per cent had illiterate, 20 
per cent had secondary education, 10 per cent had higher secondary and 17 per cent had graduate level education. Table 2 shows that people who are under graduation level were mainly engaged in mushroom cultivation.

\subsubsection{Family size of the producers}

In this study family is defined as a number of people living together and eating in the household. Permanent hired labor was not included as a member of the family. The distribution pattern of family size is shown in Table 3. Table shows that the average family size of sampled producers was about 5.13, and ranged between 2 to 12 which is comparatively larger than the average family size (4.35) of Bangladesh (BBS, 2010). The average male member of the sampled family was 2.5 , whereas the average female member was 2.63. The average dependent and independent members of the family were 2.03 and 3.07, respectively.

Table 1. Age of samples mushroom producers

\begin{tabular}{lcc}
\hline Age & Number & $\%$ \\
\hline Below 20 & 1 & 3 \\
$20-30$ & 15 & 50 \\
$30-40$ & 9 & 30 \\
$40-50$ & 3 & 10 \\
Above 50 & 2 & 7 \\
\hline Total & 30 & 100 \\
\hline
\end{tabular}

Table 2. Literacy level of the producers

\begin{tabular}{lcc}
\hline Literacy level & Number & $\%$ \\
\hline Illiterate & 6 & 20 \\
Primary & 10 & 33 \\
Secondary & 6 & 20 \\
Higher Secondary & 3 & 10 \\
Graduate \& Above & 5 & 17 \\
\hline Total & 30 & 100 \\
\hline
\end{tabular}

Table 3. Family composition of the producers

\begin{tabular}{lcccc}
\hline Particular & Mean & SD & Max & Min \\
\hline Male & 2.5 & 1.48 & 7 & 1 \\
Female & 2.63 & 1.47 & 6 & 1 \\
Dependent & 2.03 & 1.30 & 5 & 0 \\
Independent & 3.07 & 2.02 & 8 & 1 \\
\hline Total & 5.13 & 2.52 & 12 & 2 \\
\hline
\end{tabular}




\subsection{Economic analysis of mushroom production}

The cost items in the mushroom farming included different types of fixed, variable and opportunity costs. On the return side, gross return included revenue from mushroom and its by product.

\subsubsection{Fixed costs}

The fixed costs of mushroom farming considered farm house making materials as bamboos, polythene, cloths, plastic pipes, water supply pipes, tins, water supply machines, rent of house, gunny bags, woods, concrete pillars and others (electricity, water supply materials etc).

\subsubsection{Variable costs}

Variable cost share is the largest amount in the total cost of mushroom farming. Variable costs encompasses the cost of spawn bags (purchasing and making cost) and all labor cost (family and permanent hired labor) for mushroom production

\subsubsection{Labor costs}

Labor cost included family labor and permanent hired labor costs. The family labor cost was calculated on the basis of the principle of opportunity cost. The hired labor cost was calculated on the basis of the labor employed at the local market price. All types of labor costs were considered as 3-months, because commercial mushroom farmers actually produce for 3 months (6 times) in one spawn bag. Labor cost is one of the main cost items in agriculture and it is also true in mushroom farming. In case of small farm owner and family members provide their labor. However, for large farm, not only owner and family members but also hired labor works in the farm.

\subsection{Total cost of mushroom production}

The total cost of mushroom farming included all fixed and variable costs and are presented in Table 4. The average total cost of mushroom production was about Tk. 41,938 of which total fixed cost was Tk. 22,142. Cost of bamboo is one of the main fixed cost items for the mushroom farm. The bamboo cost was about Tk.
3,373 per mushroom farm and it was about 8.04 per cent of the total production cost. Some producers cultivated mushroom in rented houses. The highest fixed cost of mushroom production was rental cost of housing (Tk. 4,250) and it was about $10.13 \%$ of the total production cost. Another important fixed cost was wood.

Spawn is the main input of mushroom production. The average cost of spawn bags was about Tk. 16,136 and its share of total production cost was about 38.48 per cent. The average labor cost was about Tk. 3,660 and it was about 7.27 per cent of total cost.

\subsection{Gross total revenue, net profit and agricultural income}

\subsubsection{Agricultural income}

Average production cost, revenue, net profit and agricultural income per farm are shown in Table 5 . The average agricultural income per farm was about Tk. 31,255 of which Tk. 22,888 was net profit of mushroom production. The second largest component of agricultural income was opportunity cost of family labor and it was about Tk. 6,240.

\subsubsection{Household income}

Households in developing countries derive income from various sources. Basically mushroom producers earn household income from profit of mushroom production, labor income and non agricultural activities. The profit from mushroom production considers the revenue from mushroom sale. Labor income includes both family labor used on farm and labor sold to other farms or other sectors. Each of the components of overall household income varies widely, and depends on household endowments of human and physical capital (including land), agricultural endowments of household's own land, proximity to urban centers, and many other cultural, historical and institutional circumstances. $\quad$ Table 6 shows that overall agricultural income was remaining the principal source of income for the mushroom producers. The total household income was on an average Tk. 43,731. 
Table 4. Analysis of costs and returns of mushroom production

\begin{tabular}{|c|c|c|}
\hline Particulars & Price(Taka) & Percent $(\%)$ \\
\hline \multicolumn{3}{|l|}{ A. Fixed Cost of Mushroom Production: } \\
\hline (i) Bamboos & 3,373 & 8.04 \\
\hline (ii) Polythenes & 639 & 1.52 \\
\hline (iii) Cloths & 356 & 0.85 \\
\hline (iv) Plastic Pipes & 786 & 1.87 \\
\hline (v) Water supply pipes & 301 & 0.72 \\
\hline (vi) Tins & 693 & 1.65 \\
\hline (vii) Water supply machines & 1,116 & 2.66 \\
\hline (viii) Rent & 4,250 & 10.13 \\
\hline (ix) Gunny Bags/ Jute Bags & 168 & 0.40 \\
\hline (x) Woods & 2,005 & 4.78 \\
\hline (xi) Cement Pillars & 225 & 0.54 \\
\hline (xii) Opportunity cost of family labors & 6,240 & 14.88 \\
\hline (xiii) Opportunity cost of rent & 960 & 2.29 \\
\hline (xiv) Others & 1,030 & 2.46 \\
\hline Total Fixed Cost & 22,142 & 52.80 \\
\hline \multicolumn{3}{|l|}{ B. Variable Cost of Mushroom Production: } \\
\hline (i) Spawn Bags & 16,136 & 38.48 \\
\hline $\begin{array}{l}\text { (ii) Permanent Hired labor } \\
\text { (a) Male }\end{array}$ & 3,050 & 7.27 \\
\hline (b) Female & 300 & 0.72 \\
\hline (c) Children & 310 & 0.74 \\
\hline Total Variable Cost (3 months) & 19,796 & 47.20 \\
\hline C. Total Cost (Fixed and Variable) $(\mathrm{A}+\mathrm{B})$ & 41,938 & 100 \\
\hline \multicolumn{3}{|l|}{ D. Revenue: } \\
\hline $\begin{array}{l}\text { 1.Revenue from Mushroom } \\
\text { 2.By-Product }\end{array}$ & $\begin{array}{c}63,495 \\
1331\end{array}$ & \\
\hline E. Total Revenue & 64,826 & \\
\hline F. Net Profit (D-C) & 22,888 & \\
\hline
\end{tabular}

Notes: (i) Total sample size is 30; (ii) 1 US $\$=73$ Taka (April, 2011); (iii) Duration of mushroom cultivation is 3 months. Thus all costs are calculated based on 3 months. 
Table 5. Agricultural income of mushroom farming

\begin{tabular}{lc}
\hline Sources of Income & Taka \\
\hline (i) Net Profit & 22,888 \\
(ii) Opportunity Cost of Family Labor & 6,240 \\
(iii) Opportunity Cost of Rent & 960 \\
(iv) Agricultural wage (without mushroom) (3months) & 1,167 \\
\hline Total income & 31,255 \\
\hline
\end{tabular}

Note: (i) 1 US\$ =73 Taka (April, 2011)

Table 6. Household income of mushroom producers

\begin{tabular}{lc}
\hline Sources of Income & Taka \\
\hline 1. Net Profit & 22,888 \\
2. Opportunity Cost of Family Labor & 2,440 \\
$\quad$ (i) Male (3 months) & 3,650 \\
$\quad$ (ii) Female (3 months) & 150 \\
$\quad$ (iii) Children (3 months) & 960 \\
3. Opportunity Cost of Rent (3 months) & 1,167 \\
4. Agriculture Income (without mushroom) (3 months) & 11,833 \\
5. Off-farm Income (3 months) & 643 \\
6. Others Income (3 months) & 43,731 \\
\hline Total Household Income (3 months)
\end{tabular}

Notes: (i) Total sample size is 30 (ii) 1 US\$ $=73$ Taka (April, 2011)

Table 7. Gross margin, net return, and benefit cost ratio (BCR)

\begin{tabular}{lc}
\hline Particulars & Taka \\
\hline 1. Gross/ Total Revenue & 64,826 \\
2. Total variable cost & 26,036 \\
3. Total cost & 41,938 \\
4. Gross Margin (GM) & 38,790 \\
5. Net Return/ Profit & 22,888 \\
6. Benefit Cost Ratio (BCR) & 1.55 \\
\hline
\end{tabular}

Notes: (i) Total sample size is 30; (ii) 1 US $\$=73$ Taka (April, 2011). 


\subsubsection{Gross margin, and benefit cost ratio (BCR)}

Table 7 shows that the average gross margin was Tk. 38,790 and average net return was Tk. 22,888 . The average BCR was 1.55 for every farm. So, it could be concluded that mushroom farming is highly profitable.

\subsection{Costs and margin of mushroom production and its marketing channels}

\subsubsection{Marketing costs and margin of} mushroom production

The movement of the products from the producers to the ultimate consumers involves various types of costs such as packing, transporting, weighment charges, loading and unloading charges, losses in the transport, losses due to spoilage, taxes, etc. These costs are called marketing costs and it depends upon the marketing channels.

In general, marketing margin represents the difference between price paid and received by a given market intermediary (such as wholesaler, retailers, etc) in the marketing of a commodity. So, marketing margin is the difference between the price of a product at any two points in the marketing chain or channels. In other words, marketing margin is equal to the value of the product when it leaves the farm plus the value that is added by the marketing system. Thus, marketing margin is the amount of value created by the marketing system (Drummond and Goodwin, 2004; and Reddy et al., 2010).

Marketing margin represent the remuneration that the intermediaries (wholesalers, retailers, etc.) receive from their services in the movement of the commodity in the marketing channel. Estimation of marketing margin helps to estimate the efficiency of the marketing system. The marketing margin of mushroom production is presented in Table 8. Marketing margins of mushroom were higher for every point of marketing channels. The mean selling prices of mushroom for farm-gate, wholesalers, and retailers were Tk. 110,160 and 230 per $\mathrm{kg}$, respectively. Therefore, the marketing margin of mushroom for farm-gate to wholesalers and wholesalers to retailers were Tk. 50 and 70 per $\mathrm{kg}$, respectively. It is also revealed that the selling price of mushroom per $\mathrm{kg}$ increased by about 46 per cent from farm-gate to wholesale, whereas, it increased about 44 per cent from wholesalers to retailers. However, the selling price per $\mathrm{kg}$ mushroom increased more than double $(109 \%)$ from farm-gate to retailers. The main reason underlying high marketing margin was the limited sales of mushroom due to lack of awareness of mushroom consumption, high perishability, high spoilage rate, high transportation cost, specialized packing, etc. Thus, the producers of mushroom received only half of the price paid by the ultimate consumers and consumers paid more than double the farmgate price.

\subsubsection{Marketing channels of mushroom production}

Marketing channel is defined as a set of interdependent organizations that help make a product or service available for use or consumption by the consumers (Kotler, 2010). The chain of intermediaries through which the various farm commodities pass between producers and consumers is called marketing channel. The existence of the agricultural farm depends on the marketing channel mainly because the agricultural commodities move from farmers to ultimate consumers through various market intermediaries that operate in the marketing system and marketing efficiency.

The marketing channels of mushroom are delineated in Figure 1. Usually, three intermediaries are involved in the channel for mushroom - producers, wholesalers and retailers. Producers of mushroom sold their product to nearby mushroom office, wholesalers and retailers. The wholesalers buy mushroom directly from producers and mushroom office and sell it to retailers or sometimes directly to consumers. The retailers buy mushroom from wholesalers or directly from producers and sell it to consumers. 
Distribution of marketing channels for produced mushroom is shown in Table 9. Table 9 shows that about $73 \%$ producers sold mushroom directly to nearby mushroom office (National
Mushroom Development and Extension Centre). About $33 \%$ producers sold directly to wholesalers $(33 \%)$ and only about $27 \%$ retailers sold to retailers in the study area.

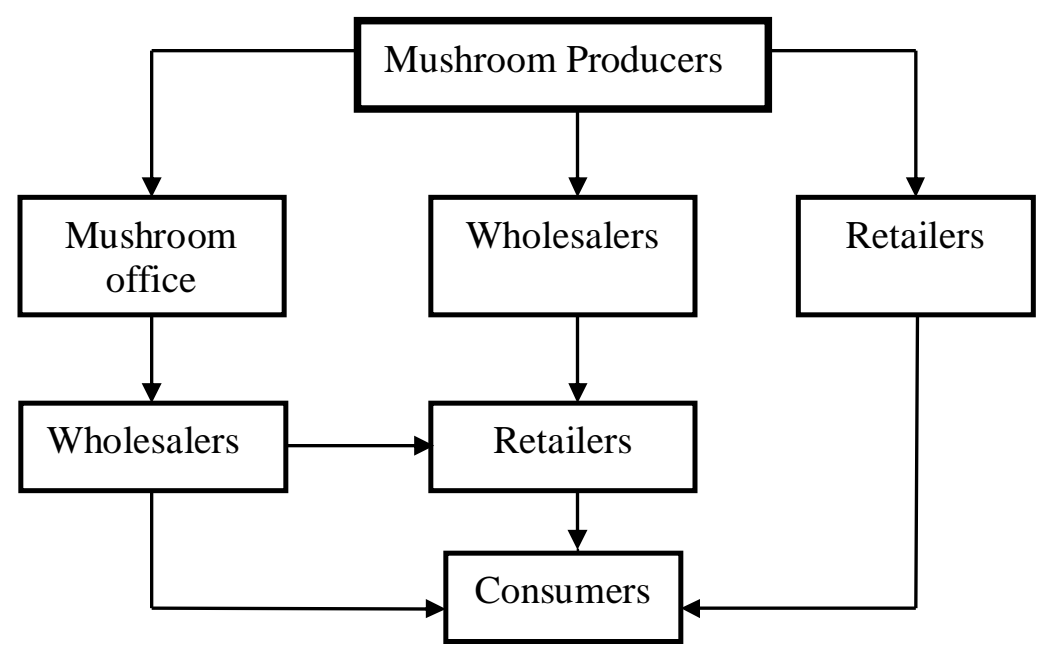

Fig. 1. Marketing channels of mushroom production

Table 8. Marketing margin (taka/kg) of mushroom at different channels

\begin{tabular}{lccc}
\hline Type & Price $(\mathrm{taka} / \mathrm{kg})$ & Marketing margin & $\%$ increase \\
\hline Farmgate & 110 & - & Farmgate to wholesale (46\%) \\
Wholesaler & 160 & 50 & Wholesale to retailer (44\%) \\
Retailer & 230 & 70 & Farmgate to retailer (109\%) \\
\hline
\end{tabular}

Table 9. Distribution of channels of mushroom to consumption

\begin{tabular}{lcc}
\hline Particular & Number & $(\%)$ \\
\hline Retailers & 8 & 27 \\
Wholesalers & 10 & 33 \\
Mushroom Office & 22 & 73 \\
Retailer and Wholesaler & 3 & 10 \\
Wholesaler and mushroom office & 5 & 17 \\
\hline
\end{tabular}

Note: (i) Total sample size is 30. 


\section{5.3. Types of customers of mushroom}

Based on the multiple responses of the mushroom producers, about $77 \%$ of the customers were from upper-income, $37 \%$ were from middle-income and only $13 \%$ were from poor-income group. In addition, about $58 \%$ customers consume mushroom frequently in their meal (Table 10). Therefore, it may be concluded that mainly rich and middle income people are the main consumers of mushroom.

\subsection{Problems and constraints of mushroom production}

Mushroom producers face many problems from cultivation to final consumption. These problems are related to production, marketing, technical and awareness and briefly discussed in this section.

\subsubsection{Production problems}

Mushroom is a new crop in Bangladesh and most of the farmers are facing many problems (Table 11). About $67 \%$ of the sampled producers expressed that fly and cockroaches destroy mushroom spawn. The main reason is that dark place is required for mushroom production and fly and cockroaches also like that environment and thus they eat mushroom spawn. About $40 \%$ producers mentioned that high temperature hinders mushroom production, about $37 \%$ producers faced virus, fungus and germ problems and about $23 \%$ said that they faced capital problem. In addition to these, the producers also faced high price of raw materials, difficulty of loan process, land scarcity and good mother spawn problems in mushroom cultivation.

\subsubsection{Marketing problems}

The marketing problems faced by the sampled producers are mentioned in Table 12. About $49 \%$ sampled producers complained against available market facility where they sell their product and about $43 \%$ producers could not sell directly their products to retailers. The main reason is the communication gap and lack of awareness about mushroom. In addition, the sampled producers also faced advertising problems and lack information about mushroom production.

\subsubsection{Technical problems}

Along with production and marketing problems, technical problems also hinder the smooth mushroom production in Bangladesh (Table 13). Most of the sampled farmers faced Air Cooler (AC) problem (50\%), experienced labor shortage $(30 \%)$, electricity problem $(60 \%)$ and training problem $(40 \%)$ for optimum mushroom production. In addition to these, some farmers mentioned of instrument, water tank, steel shelf and lack of training in mushroom production.

\subsubsection{Awareness problems}

Table 14 shows that about $80 \%$ producers claimed that few consumers have no knowledge about mushroom consumption and its medicine and nutritional values. Only the urban residents had sufficient knowledge about mushroom consumption and the number of consumers in urban area is significantly increasing. About $75 \%$ producers explained that most of the people, especially rural people think it is fungus (frog umbrella) and about 14\% said that most of the people do not know the medicine and nutrition values of mushroom.

Table 10. Type of consumers of mushroom consumption

\begin{tabular}{lcc}
\hline Types of consumers & Number & $\%$ \\
\hline Upper income group & 23 & 77 \\
Middle income group & 11 & 37 \\
Lower income group & 4 & 13 \\
\hline All & 17 & 58 \\
\hline
\end{tabular}


Table 11. Production problems faced by Producers

\begin{tabular}{lcc}
\hline Problems & Number & $(\%)$ \\
\hline Fly and cockroach & 20 & 67 \\
Cultivation house & 4 & 13 \\
Available good spawn & 2 & 7 \\
Hot temperature & 12 & 40 \\
Capital & 7 & 23 \\
High price of raw materials & 4 & 13 \\
Time maintain & 3 & 10 \\
Virus, fungus and germ & 11 & 37 \\
Loan & 3 & 10 \\
\hline
\end{tabular}

Table 12. Marketing problems faced by producers

\begin{tabular}{lcc}
\hline Problems & Number & $(\%)$ \\
\hline Advertising & 10 & 25 \\
Direct sale to retailers & 20 & 43 \\
Available markets & 25 & 49 \\
Unknown product & 15 & 23 \\
Others & 3 & 10 \\
\hline
\end{tabular}

Table 13. Technical problems faced by producers

\begin{tabular}{lcc}
\hline Problems & Number & $(\%)$ \\
\hline Air Conditioner (A.C.) & 23 & 50 \\
Experienced labor & 14 & 30 \\
Instrument & 1 & 3 \\
Electricity & 30 & 60 \\
Water tank & 1 & 3 \\
Steel shelf & 1 & 3 \\
Training & 10 & 40 \\
Inefficiency & 2 & 7 \\
Others & 2 & 7 \\
\hline
\end{tabular}


Table 14. Awareness problems faced by mushroom Producers

\begin{tabular}{lcc}
\hline Problems & Number & $(\%)$ \\
\hline Lack of knowledge & 24 & 80 \\
Fungus problems & 22 & 75 \\
Others & 5 & 14 \\
\hline
\end{tabular}

Table 15. Suggestion of producers for good mushroom cultivation

\begin{tabular}{lcc}
\hline Suggestions & Number & $\%$ \\
\hline Need more advertising for awareness & 30 & 100 \\
Reduce market price of inputs & 20 & 72 \\
Increase market price of mushroom & 26 & 88 \\
Availability of good mushroom spawn & 22 & 74 \\
Need more extension and training for producers & 15 & 50 \\
Provide easy loan program & 14 & 43 \\
\hline
\end{tabular}

\section{Recommendations}

To overcome the problems faced by the producers regarding smooth production and marketing, the sampled farmers provided some suggestions that are presented in Table 15. All farmers have suggested that advertisement is needed to overcome the negative concept about mushroom as well as the development of mushroom industry in Bangladesh. The main reason is that most of the people still believe that mushroom is a toxic fungi and it is harmful for health. About $72 \%$ farmers suggested reducing the price of inputs for rapid growth of mushroom industry. The main reason is that if production cost increases, the market price of mushroom will also increase and thus restrict marketing. About $88 \%$ farmers claimed that the market price of mushroom should increase or the government should subsidize inputs. About $74 \%$ farmers suggested that mushroom office should provide good quality spawn at cheaper price. About $50 \%$ farmers expected that more training and extension work are needed for smooth growing of mushroom. Only $43 \%$ farmers suggested that easy bank loan is needed because most of the mushroom producers are marginal, poor, and women.

\section{Conclusions}

Mushroom is an economically profitable and promising agricultural enterprise in Bangladesh. Usually, small, marginal and landless farmers are engaged in mushroom cultivation mainly because small piece of land, and little amount of money are required as capital. Average production cost of mushroom per farm was Taka 41,948 and revenue was Taka 64,826. Therefore, the average profit and gross margin (GM) per farm were Taka 22,888 and Taka 38,790, respectively. The benefit cost ratio (BCR) was about 1.55. Marketing costs and margins are relatively higher than those of other agricultural products in Bangladesh. The marketing margins of mushroom from farm-gate to wholesalers and wholesalers to retailers were Tk. 50 and 70 per kilogram, respectively. Smooth marketing 
channels are required for optimal mushroom production. Three intermediaries - mushroom office, wholesalers and retailers are involved in the mushroom marketing channels. Mushroom producers are facing many problems relating to productions, which are high price of spawn, infestation of fly and cockroaches, and high temperature, marketing, technical and awareness problems. Economically solvent, rich and middle income group people are the main customers of mushroom in Bangladesh. A large number of small, marginal and landless poor farmers as well as women can earn a significant amount of money from mushroom cultivation that can help reduce poverty and create employment opportunity in Bangladesh.

\section{References}

Agrahar-Murugkar, D. and Subbulakshmi, G. 2005. Nutritional Value of Edible Wild Mushrooms collected from the Khasi Hills of Meghalaya. Food Chemistry, 89: 599-603.

Amin, S. R. 2002. Performance of Different Oyster Mushroom (Pleurotus spp.) Varieties. M.S. Thesis, Bangabandhu Sheikh Mujibur Rahman Agricultural University, Gazipur, 1-50 pp.

Amin, S., and Ruhul, M. 2008. Mushroom in Bangladesh: Past, Present and Future. Abstract of the Annual Botanical Conference 2007, March 7-9, Abstract no - 122, JU, Savar, Dhaka, 61p.

Bano, L. Rajarathnam, S. and Nagraja. N. 1979. Some Aspects on the Cultivation of Pleurotus flabellatus in India. Mushroom Science, 10(2): 597-608.

BBS, 2010. Bangladesh Bureau of Statistics. Statistical Yearbook of Bangladesh. Planning Division, Ministry of Planning, Government of the People's of Bangladesh, 2009.

Block, S. Tsao, S. and Han, I. 1958. Production of Mushroom from Sawdust. Journal of Food Chemistry, 6: 923-927.
Cheung, L. M. and Cheung, P. C. K. 2005. Mushroom Extracts with Antioxidant Activity against Lipid Peroxidation. Food Chemistry, 89:403-409.

Drummond, H. E. and Goodwin, J. W. 2004. Agricultural Economics, $2^{\text {nd }}$ edn., Pearson Education Inc, One Lake Street, Upper Saddle River, NJ07458, USA, 329 p.

Ferchak, J. D. and Croucher, J. 2001. Prospects and Problems in Commercialization of Small-Scale Mushroom Production in South and Southeast Asia, Appropriate Technology International, Washington DC, USA, 321-329 pp.

Gunde-Cimerman, N. 1999. Medicinal Value of the Genus Pleurotus (Fr.) P. Karst (Agaricles S. R., Basidiomycetes). International Journal of Medicinal Mushrooms, 1:69-70.

Han,Y. H. Chen., K. M. and Cheng, S. 1977. Characteristics and Cultivation of New Pleurotus In Taiwan. Mushroom Science, 9(2):167-173.

Hawksworth, D. L. 2001. Mushrooms: The Extent of the Unexplored Potential. International Journal of Medicinal Mushrooms, 3:333-340.

Jong, S. C. and Peng, J. T. 1975. Identity and Cultivation of a New Commercial Mushroom in Taiwan. Mycologia, 67:1235-1238.

Kamal, A. S. Begum, F. and Khair, S. 2009. Mushroom Production in Bangladesh: Scenario and Potentialities. SAARC Journal of Agriculture, 7(2):91-105.

Khan, S. M. Kausar, A. G. and Ali, M. A. 1981. Yield Performance of Paddy Straw in Pakistan. Mushroom Science, 2(1):675687.

KIT, Mali, F. IIRR, 2006. Chain Empowerment: Supporting African Farmers to Develop Markets, Amsterdam: Royal Tropical Institute. 
Kotler, P., and Armstrong, G, 2010. Principles of Marketing, $13^{\text {th }}$ edn., Prentice Hall, 339 p.

Lelley, J. 1988. Growing Edible MushroomsStill a Generally Neglected Opportunity. Gate 4, 30-34 pp.

Reddy, S. S. Ram, P. R. Sastry, T. V. N. and Devi, I. B. 2010. Agricultural Economics, Oxford \& IBH Publishing Co. Pvt. Ltd. New Delhi 110049, India, 525-532 pp.

Sarker, N. C. Hossain, M. M. Sultana, N. Mian, I. H. Karim, A. J. M. S. and Amin, S. M. R. 2007. Effect of Frequency of Watering on the Growth and Yield of Oyster Mushroom (Pleurotus ostreatus (Jacquin ex Fr.) Kummer). Bangladesh Journal of Mushroom, 1(1): 29-37.

Shepherd, A. W. 2006. Approaches to link producers to Markets- A Review of Experiences to Date, Agricultural Management, Marketing and Finance, Occasional paper No. 13, Rome, FAO.
Suman, B.C. and Sharma, V.P. 2007. Mushrooms Cultivation in India, Daya Publishing House, Delhi.-110035, 18-22 pp.

Suzuki, S. and Oshima, S. 1976. Influence of Shii-te-ke (Lentina edodes) on Human Serum Cholesterol. Mushroom Science, 1: 463-T.

Uddin, M. N. Yesmin, S. Khan, M. A. Tania, M. Moonmoon, M. and Ahmed, S. 2011. Production of Oyster Mushrooms in Different Seasonal Conditions of Bangladesh. Journal of Scientific Research, 3(1): 161-167.

Zamil, M. F. and Cadilhon, J. J. 2009. Developing Small Production and Marketing Enterprise: Mushroom Contract Farming in Bangladesh. Development in Practice, 19(7): 923-932. 